\title{
Microbial Distribution in the Root Canal System After Periapical Lesion Induction Using Different Methods
}

\author{
Juliane Maria Guerreiro TANOMARU ${ }^{1}$ \\ Mario Roberto LEONARDO ${ }^{1}$ \\ Mário TANOMARU-FILHO ${ }^{1}$ \\ Léa Assed Bezerra da SILVA² \\ Izabel Yoko ITO $^{3}$ \\ ${ }^{1}$ Department of Restorative Dentistry, Dental School of Araraquara, \\ São Paulo State University, Araraquara, SP, Brazil \\ ${ }^{2}$ Department of Pediatric Clinic, Preventive and Community Dentistry, \\ Dental School of Ribeirão Preto,University of São Paulo, Ribeirão Preto, SP, Brazil \\ ${ }^{3}$ Department of Microbiology and Immunology, School of Pharmaceutical Sciences of Ribeirão Preto, \\ University of São Paulo, Ribeirão Preto, SP, Brazil
}

\begin{abstract}
The aim of this study was to evaluate the microbial distribution in the root canal system after periapical lesion induction in dogs' teeth using different methods. Fifty-two root canals were assigned to 4 groups $(n=13)$. Groups I and II: root canals were exposed to the oral cavity for 180 days; groups III and IV: root canals were exposed for 7 days and then the coronal openings were sealed for 53 days. The root apices of groups I and III were perforated, while those of groups II and IV remained intact. After the experimental periods, the animals were euthanized and the anatomic pieces containing the roots were processed and stained with the Brown \& Brenn method to assess the presence and distribution of microorganisms. The incidence of microorganisms at different sites of the roots and periapical lesions was analyzed statistically by the chi-square test at 5\% significance level. All groups presented microorganisms in the entire root canal system. A larger number of microorganisms was observed on the root canal walls, apical delta and dentinal tubules ( $\mathrm{p}<0.05)$, followed by cementum and cemental resorption areas. In spite of the different periods of exposure to the oral environment, the methods used for induction of periapical periodontitis yielded similar distribution of microorganisms in the root canal system.
\end{abstract}

Key Words: pulp cavity, pulp necrosis, endodontics, microorganisms, periapical periodontitis.

\section{INTRODUCTION}

The biological effects of root canal filling materials and substances employed in the different phases of the root canal treatment may be investigated by 'usage tests', which is the ANSI/ADA denomination for evaluation methods that reproduce in primates and dogs the clinical conditions of usage of dental materials (1).

Regarding teeth with apical periodontitis, the presence of bacteria after pulp necrosis is fundamental for the establishment of periapical pathosis (2). In teeth with necrotic pulp, bacteria are initially restricted to the root canal system. However, the dentinal tubules and canal ramifications (3) are important areas of propagation, contributing to the establishment of a large number of bacterial morphotypes.

The methods for induction of periapical periodontitis used in endodontic research should reproduce the microbiological conditions of the root canal system. In this way, the use of these experimental models and the correct interpretation of the results shall provide evidence-based results that will contribute to the improvement of endodontic treatment.

In studies using animal models, periapical peri-

Correspondence: Prof. Dr. Mário Tanomaru Filho, Departamento de Endodontia, Faculdade de Odontologia de Araraquara, UNESP, Rua Humaitá, 1680, 14801-903 Araraquara, SP, Brasil. Tel: +55-16-3336-4658. Fax:+55-16-3301-6392. e-mail: tanomaru@uol.com.br 
odontitis may be experimentally induced by different methods. Different periods of exposure to the oral cavity for contamination of the root canals can be used as well as filling or not of the coronal opening during the process of development of periapical periodontitis. Several authors (4-8) have used coronal filling after root canal contamination in such a way that the periapical periodontitis is induced within a shorter period of time. Other authors (9-12) maintain the root canals exposed to the oral cavity for longer periods. Another variable that can be added to the methods of experimental induction of periapical periodontitis is the perforation of the foramen present in the root apex of dogs' teeth.

In a radiographic and microbiologic study in dogs' teeth, Tanomaru Filho et al. (13) compared different techniques of experimental induction of periapical periodontitis, with or without coronal sealing. The authors observed the presence of root canal microbiota with predominance of strictly anaerobic microorganisms and found that the different methods induced similar areas of periapical radiolucency.

In an experimental method for assessment of teeth with periapical lesions, another factor to be considered is the presence of microorganisms in the entire root canal system and the apical cementum. In this region, apical biofilm formation contributes to the development and maintenance of the chronic periapical reaction, which has been noticed in other studies involving teeth with periapical periodontitis $(3,14)$. Despite the large number of studies addressing the experimental induction of periapical lesions within different periods, there are no studies describing the microbial distribution pattern in the root canal system and apical cementum after periapical lesion induction by the different techniques. The reproduction of these microbiological conditions is of paramount importance for the evaluation of materials and techniques in in vivo models of teeth with periapical lesion.

Given that microbial diffusion into the root canal system and apical cementum is an important factor for reproducing the conditions of teeth with periapical lesion, the aim of this study was to evaluate the microbial distribution in the root canal system after periapical lesion induction in dogs' teeth using different methods.

\section{MATERIAL AND METHODS}

The second, third and fourth mandibular premolars and second and third maxillary premolars of 3 dogs, totaling 52 root canals, were selected for treatment. The study design and experimental protocols were in accordance with the guidelines of the Committee of Animal Experimentation of the School of Dentistry of Araraquara.

The animals were anesthetized intravenously with 3\% sodium thiopental (Thionembutal; Abbot Laboratories, Rio de Janeiro, RJ, Brazil). After preparation of the occlusal access cavities, the coronal pulp was removed, the root canals were explored with a size 20 K-file (Dentsply Maillefer, Ballaigues, Switzerland) and the root pulp tissue was extirpated with a size 20 Hedström file (Dentsply Maillefer).

The root canals were assigned to 4 groups $(n=13)$ according to the time of placement of coronal filling and apical perforation. In groups I and II, root canals were exposed to the oral cavity for 180 days. One-hundred and twenty days after the procedures in groups I and II, the root canals of the other quadrants of the same dog were exposed to the oral cavity for 7 days, after which time the coronal openings was restored and remained sealed for 53 days. These root canals were included in groups III and IV.

In groups I and III, after coronal access and pulpectomy, the root apical delta was perforated using sequential sizes 20,25 and $30 \mathrm{~K}$-files up to the total length of the root in order to create a standardized apical opening. All experimental groups were tested in the same animal and were performed in alternate quadrants.

The dogs were euthanized by anesthetic overdose 180 days after coronal opening in groups I and II and 53 days after coronal sealing in groups III and IV. The maxillas and mandibles were removed and fixed in sodium cacodylate solution containing sucrose and glutaraldehyde. The specimens were then washed and demineralized in EDTA solution and glutaraldehyde activated in a microwave oven. Serial 6 - $\mu$ m-thick sections were obtained and stained with the Brown \& Breen method for histomicrobiological analysis.

The presence of microorganisms was assessed by optical microscopy with oil immersion in the apical $3 \mathrm{~mm}$ of the root canal system and in the periapical region at the following sites: 1- main canal walls, 2apical delta ramifications, 3- cementum, 4- dentinal tubules, and 5- areas of cemental resorption. After analysis of all histological sections selected from each root, the presence or absence of microorganisms was recorded for each evaluated region. The incidence of 
microorganisms at different sites of the roots and periapical lesions was analyzed statistically by the chisquare test at $5 \%$ significance level.

\section{RESULTS}

A total of 312 serial sections stained with the Brown \& Brenn method were obtained from the 52 root canals. The topographical distribution of microorganisms in the apical $3 \mathrm{~mm}$ of the root canal system and periapical region of the 4 groups is given on Table 1 .

There were no statistically significant differences ( $p>0.05$ ) among the groups regarding the presence of microorganisms in the apical delta, cementum, root canal walls, dentinal tubules and cemental resorption areas.

GI (180-day exposure with apical perforation; $n=13$ ): Microorganisms were observed on the root canal walls of all specimens, being detected in the apical delta, dentinal tubules and cemental lacunae in $84.6 \%$, $69.2 \%$ and $61.5 \%$ of the cases, respectively (Figs. 1 and 2). Biofilms were identified on the root canals walls, apical delta canals and apical cementum.

GII (180-day exposure without apical perforation; $n=13$ ): Microorganisms were present on the root canal walls of all specimens, being detected in the apical delta and dentinal tubules in $84.6 \%$ and $53.8 \%$ of the cases, respectively.

GIII (7-day exposure and coronal sealing with apical perforation; $n=13$ ): Microorganisms were found on the root canal walls of all specimens, being detected in the apical delta, dentinal tubules and cementum in $84.6 \%, 76.9 \%$ and $38.5 \%$ of the cases, respectively (Figs. 3 and 4). These microorganisms produced biofilms mainly on root canal walls, apical delta canals and apical cementum.

GIV (7-day exposure and coronal sealing without apical perforation; $n=13$ ). Microorganisms were present in the root canal walls of all specimens, being detected in the apical delta and dentinal tubules in $92.3 \%$ and $76.9 \%$ of the cases, respectively (Figs. 5 and 6).

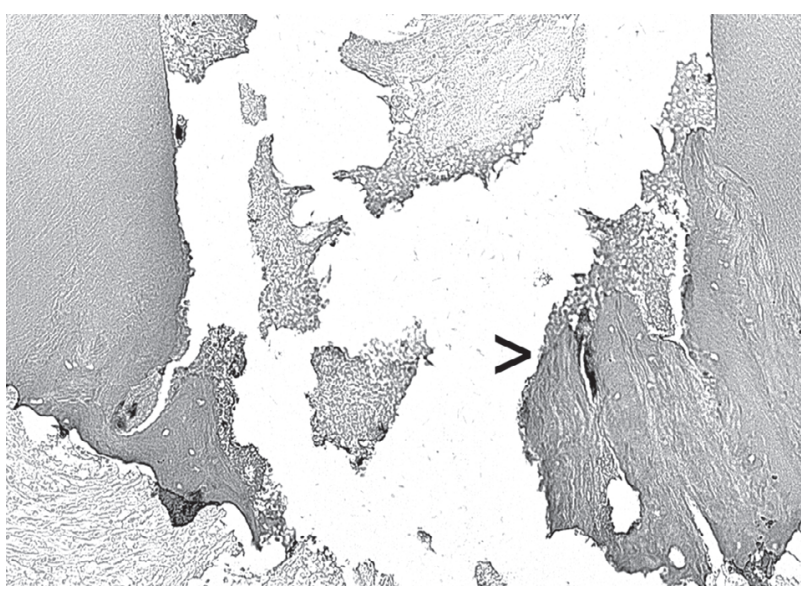

Figure 1. Region of the root apex with the presence microorganisms and biofilm. (Brown \& Brenn $\times 100$ ).

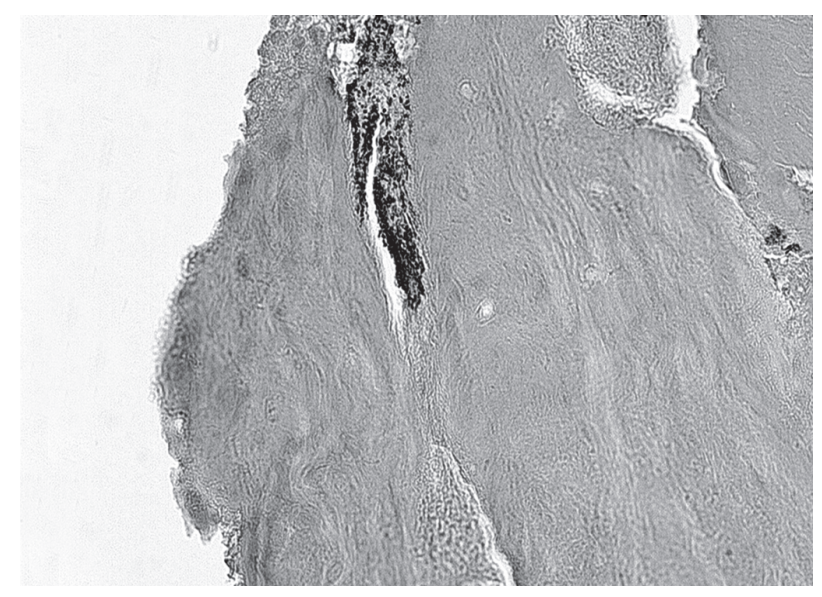

Figure 2. Area of arrow in Figure 1. Gram-positive bacteria (black) on the apical delta ramification and Gram-negative bacteria on the apical foramen wall. (Brown \& Brenn $\times 400$ ).

Table 1. Topographical distribution of microorganisms in the apical $3 \mathrm{~mm}$ of the root canal system and periapical region.

\begin{tabular}{lccccc}
\hline Groups & Apical delta & Cementum & Main canal walls & Dentinal tubules & Cemental resorption areas \\
\hline GI $(\mathrm{n}=13)$ & $11(84.6 \%)$ & $8(61.5 \%)$ & $13(100 \%)$ & $9(69.2 \%)$ & $6(46.2 \%)$ \\
GII $(\mathrm{n}=13)$ & $11(84.6 \%)$ & $4(30.8 \%)$ & $13(100 \%)$ & $7(53.8 \%)$ & $1(7.7 \%)$ \\
GIII $(\mathrm{n}=13)$ & $11(84.6 \%)$ & $5(38.5 \%)$ & $13(100 \%)$ & $10(76.9 \%)$ & $4(30.8 \%)$ \\
GIV $(\mathrm{n}=13)$ & $12(92.3 \%)$ & $9(69.23)$ & $13(100 \%)$ & $10(76.9 \%)$ & $3(23.1 \%)$ \\
\hline
\end{tabular}




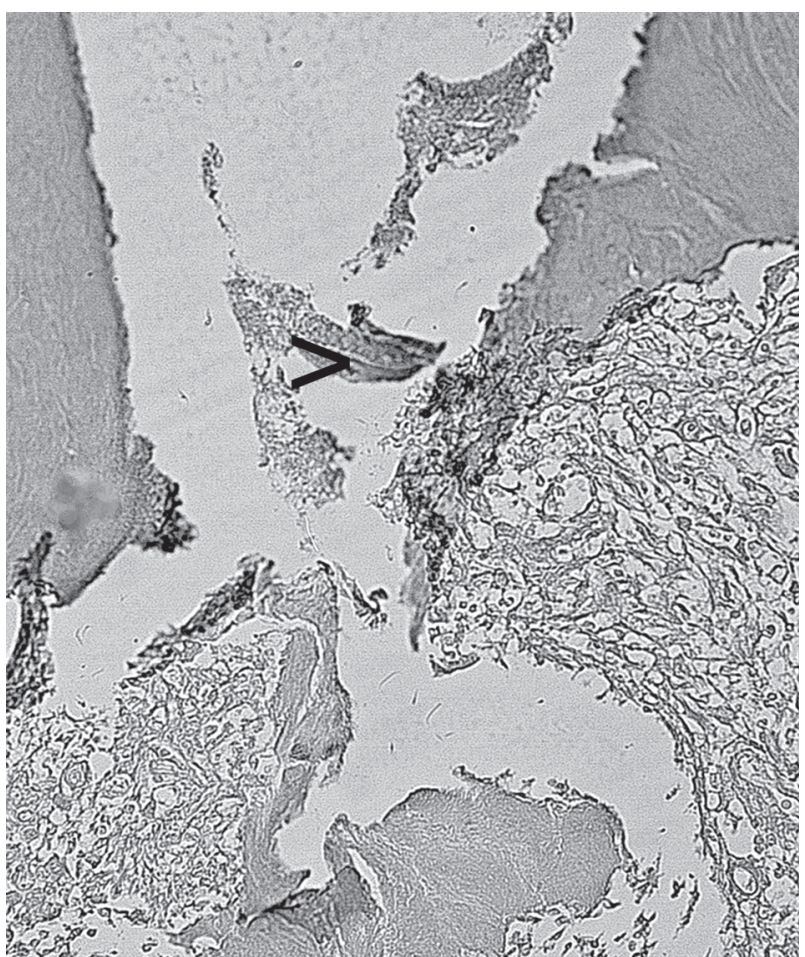

Figure 3. Region of the root apex, showing the presence microorganisms and biofilm (Brown \& Brenn $\times 100$ ).

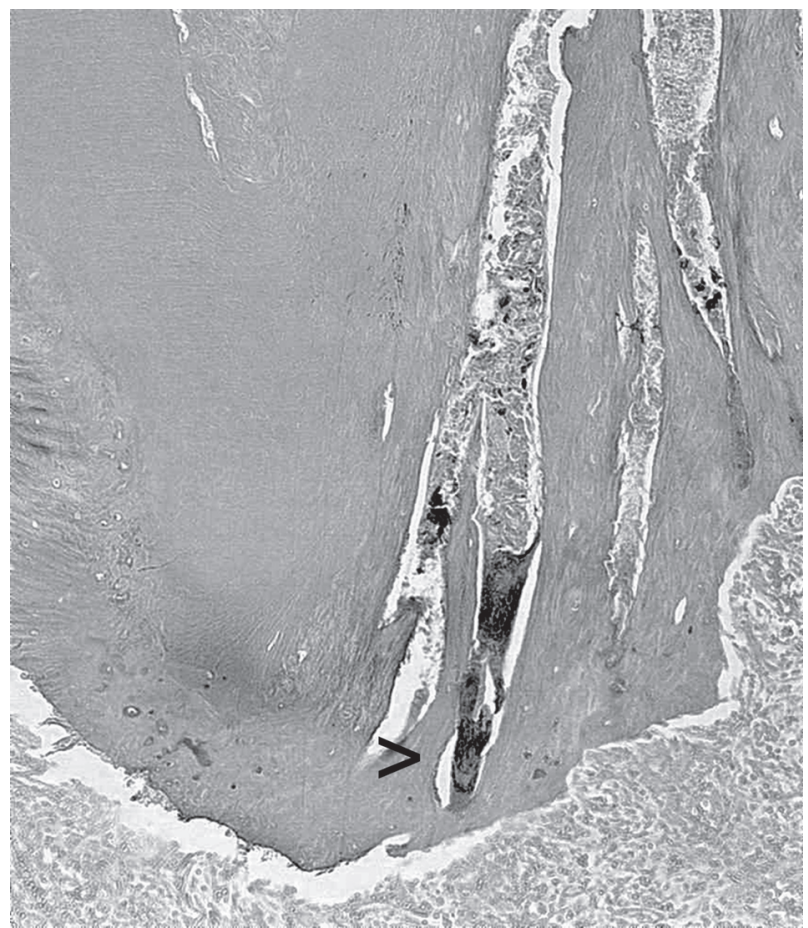

Figure 5. Apical delta presenting microorganisms in the delta canals and apical cementum (Brown \& Brenn $\times 100$ ).

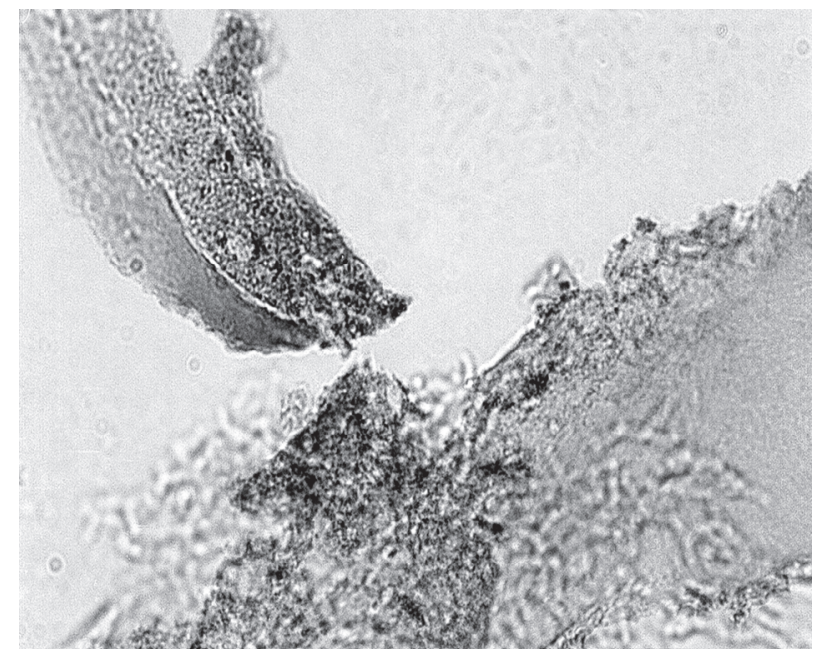

Figure 4. Area of arrow in Figure 3. Biofilm formation on internal root canal wall, with predominance of Gram-negative microorganisms (Brown \& Brenn $\times 1000)$.

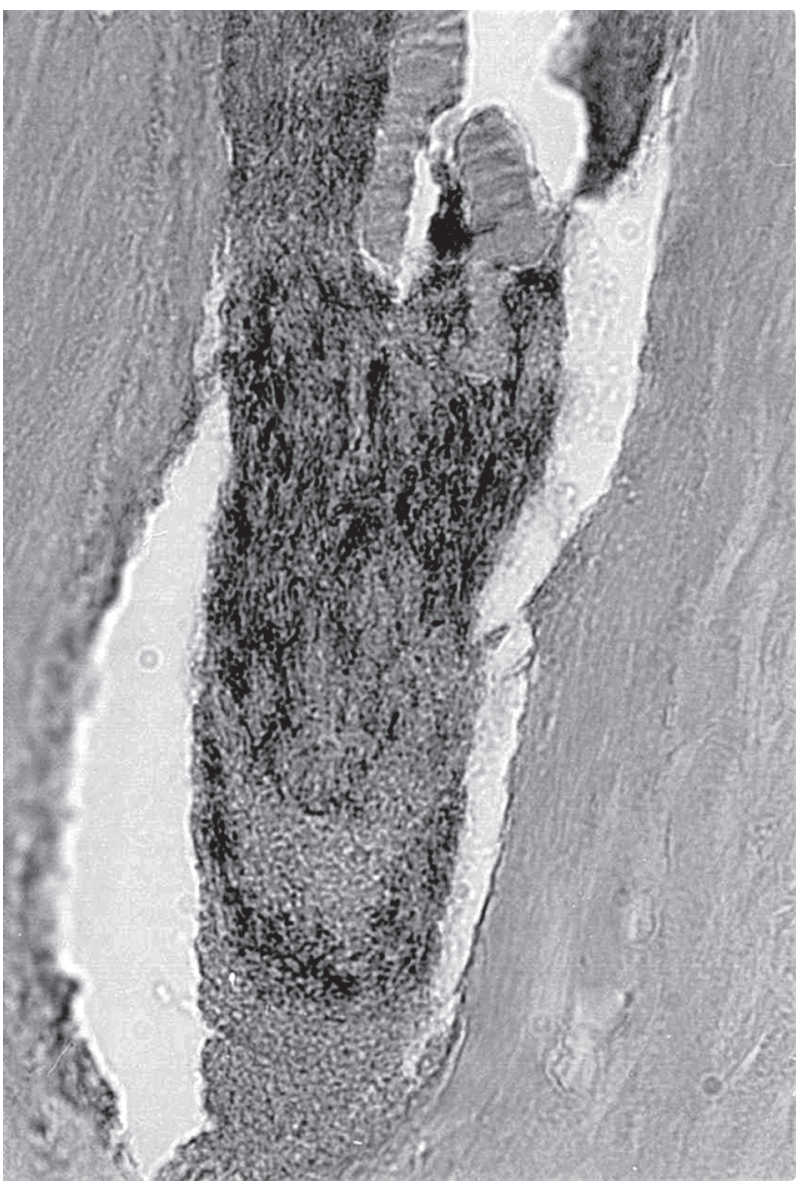

Figure 6. Area of arrow in Figure 5. Note agglomeration of microorganisms in the apical delta (Brown \& Brenn $\times 1000$ ). 


\section{DISCUSSION}

The endodontic treatment of teeth with chronic periapical reaction has a more unfavorable prognosis and lower success rate due to the involved microbiota and its diffusion within the root canal system and apical cementum $(2,14)$.

Among the available methodologies to investigate endodontic infection, the Brown \& Brenn staining offers information about the topographical location, morphology and gram-positive or gram-negative structure of microorganisms in the tissue $(4,15)$. The original histological process produced significant damage to the cell walls of gram-negative bacteria due the aggressive acids involved (16). In this study, fixation and demineralization were undertaken using glutaraldehyde, sucrose, sodium cacodylate and EDTA, which replaced the original formic acid and sodium nitrate. Furthermore, microwave activation has been shown to reduce the demineralization time (17).

In a previous study (4), the root canals of dogs' teeth were exposed to the oral cavity for 7 days to allow contamination of the root canals and induce the formation of chronic periapical lesions. After this period, the coronal openings were sealed until periapical radiolucencies were observed radiographically, which usually occurred within 45-60 days. This methodology has also been used in other studies $(4-8,13,18)$.

Jansson et al. (9), using two methods to induce periapical periodontitis with and without coronal restoration, observed that when the pulp chambers were closed, the radiolucencies were formed more rapidly than when they were left open, which indicates that a closed environment is more favorable to the development of selective anaerobic gram-negative bacteria.

A former study by Tanomaru-Filho et al. (13) demonstrated that different methods for experimental induction of periapical periodontitis, with or without coronal sealing, produced similar radiographic periapical lesions and microbiota with predominance of anaerobic microorganisms. The findings of the present study demonstrated that the methods for induction of chronic periapical lesions, even with different experimental periods, allow the diffusion of microorganisms within the entire root canal system, including the root canal walls, cemental lacunae, apical delta ramifications and the dentinal tubules.

In the present investigation, the apical third was analyzed because it represents the region were microbial propagation is more complex, with a larger number of ramifications of the main root canal. Additionally, the apical cementum presents an important region of endodontic infection, lodging microorganisms in its resorbed areas. Numerous microorganisms were identified in all examined sites, which is in agreement with the findings of previous microbiological studies with root canals of teeth with periapical periodontitis $(3,13)$. In addition, periapical biofilms were clearly observed, as previously reported in scanning electron microscopic study (14). Leonardo et al. (4) evaluated the root canal system microbiota after two different endodontic techniques, being performed experimental induction of periapical lesions associated with the coronal sealing method. Microorganisms were found in all regions of the root canal system, suggesting that the method of experimental induction of periapical lesions allowed microbial propagation. Soares et al. (19) evaluated the presence of microorganisms in the root canal system after placement of intracanal medication in dog's teeth with periapical lesion, being used the method of induction of periapical lesions with coronal sealing for 60 days. Brown and Brenn staining identified microorganisms compatible with root canal system infection.

This study showed biofilm formation after a relatively short time interval (60 days) for induction periapical lesions. The results of the present study revealed an endodontic infection pattern compatible with the one observed in teeth with periapical periodontitis, that is, an intense microbial diffusion within the entire root canal system, including apical delta ramifications and apical cemental region.

Ferreira et al. (20) evaluated the microbiota of root canals after inducing periapical lesions in dogs' teeth using two different methods, with and without coronal sealing, for a 120 -day period. The microbiota was collected only from the main canal. The authors observed a larger number of strictly anaerobic microorganisms in the teeth that were sealed compared to those exposed to the oral environment.

In the present study, a 60-day period was used for the sealed root canals and a 180-day period for those left exposed to the oral cavity, which has been described in previous studies $(4-13,18)$. The findings indicate that, in spite of the shorter period for induction of periapical periodontitis (60 days), the groups in which coronal sealing was performed presented similar microbial dif- 
fusion to those without coronal sealing, which used a longer experimental period (180 days). Both methods used for induction of periapical periodontitis yielded similar distribution of microorganisms in the root canal system, irrespectively of time for lesion induction.

\section{RESUMO}

O objetivo deste estudo foi avaliar a distribuição microbiana no sistema de canais radiculares após indução de lesões periapicais em dentes de cães por diferentes métodos. Cinqüenta e dois canais radiculares foram divididos em 4 grupos $(n=13)$. Grupos I e II: canais radiculares foram expostos por 180 dias; grupos III e IV: canais radiculares foram expostos por 7 dias e então as aberturas coronárias foram seladas por 53 dias. Os ápices radiculares dos grupos I e III foram arrombados, enquanto os dos grupos II e IV foram mantidos intactos. Após os períodos experimentais, os animais foram mortos e as peças foram processadas e coradas pelo método de Brown e Brenn para avaliação da presença ou ausência e distribuição dos microrganismos. A incidência de microrganismos nas diferentes regiões das raízes e lesões periapicais foi analisada estatisticamente pelo Teste Qui-Quadrado em nível de 5\% de significância. Todos os grupos apresentaram microrganismos em todo o sistema de canais radiculares. Um maior número de microrganismos foi observado nas paredes do canal radicular, delta apical e túbulos dentinários, seguido pelo cemento e áreas de reabsorção cementária. Apesar de utilizar diferentes períodos de exposição dos canais radiculares ao meio bucal, os métodos usados para indução das lesões periapicais permitiram semelhante distribuição de microrganismos no sistema de canais radiculares $(p>0,05)$.

\section{REFERENCES}

1. Watts A, Paterson RC. "Usage" testing of root canal sealing materials. A critical review. J Dent 1992;20:266-271.

2. Nair PN. On the causes of persistent apical periodontitis: a review. Int Endod J 2006;39:249-281.

3. Nair PN, Henry S, Cano V, Vera J. Microbial status of apical root canal system of human mandibular first molars with primary apical periodontitis after "one-visit" endodontic treatment. Oral Surg Oral Med Oral Pathol Oral Radiol Endod 2005;99:231-252.

4. Leonardo MR, Almeida WA, Ito IY, Silva LAB. Radiographic and microbiological evaluation of posttreatment apical and periapical repair of root canals of dog's teeth with experimentally induced chronic lesion. Oral Surg Oral Med Oral Pathol Oral Radiol Endod 1994;78:232-238.

5. Shabanhang S, Torabinejad M, Boyne PP, Abedi H, McMillan P. A comparative study of root end induction using osteogenic protein-1, calcium hydroxide and mineral trioxide aggregate in dogs. J Endod 1999;25:1-5.

6. Leonardo M, Silveira FF, Silva LA, Tanomaru Filho M, Utrilla LS. Calcium hydroxide root canal dressing. Histopathological evaluation of periapical repair at different time periods. Braz Dent J 2002;13:17-22.
7. Tanomaru Filho M, Leonardo M, Silva LAB. Effect of irrigating solution and calcium hydroxide root canal dressing on the repair of apical and periapical tissues of teeth with periapical lesion. J Endod 2002;28:295-299.

8. Cruz RM, Barbosa SW. Histologic evaluation of periradicular tissues in dogs treated with calcium hydroxide in combination with HCT20 and camphorated p-chlorophenol. Oral Surg Oral Med Oral Pathol Oral Radiol Endod 2005;100:507-511.

9. Jansson L, Ehnevid H, Lindskog S, Blomlof L. Development of periapical lesions. Swed Dent J 1993;17:85-93.

10. Holland R, Otoboni Filho JA, de Souza V, Nery MJ, Bernabé PF, Dezan E Jr. A comparison of one versus two appointment endodontic therapy in dogs' teeth with apical periodontitis. J Endod 2003;29:121-124.

11. Estrela C, Holland R, Bernabé PF, Souza V, Estrela CR. Antimicrobial potencial of medicaments used in healing process in dog's teeth with apical periodontitis. Braz Dent J 2004; 15:181-185.

12. Bernabé, PFE, Holland R, Morandi R, Souza V, Nery MJ, Otoboni Filho JA et al.. Comparative study of MTA and other materials in retrofilling of pulpless dog's teeth. Braz Dent J 2005; 16:149-155.

13. Tanomaru-Filho M, Poliseli-Neto A, Leonardo M, Silva LAB, Tanomaru JMG, Ito IY. Methods of experimental induction of periapical periodontitis. Microbiological and radiographic evaluation. Int Endod J 2005;38:477-482.

14. Leonardo MR, Rossi MA, Silva LAB, Ito IY, Bonifácio KC. Evaluation of bacteria biofilm and microorganisms on the apical external root surface of human teeth. J Endod 2002;28:815-818.

15. Matsuo T, Shirakami T, Ozaki K, Nakanishi T, Yumoto H, Ebisu S. An immunohistological study of the localization of bacteria invading root pulpal walls of teeth with periapical lesions. J Endod 2003;29:194-200.

16. Wijnbergen M, van Mullem PJ. The cumulative effect of disinfection, storage, histological fixation and demineralization on number and staining ability of gram-positive bacteria. Int Endod J 1991;24:243-248.

17. Tanomaru JM, Leonardo MR, Tanomaru Filho M, Bonetti Filho I, Silva LAB. Effect of different irrigation solutions and calcium hydroxide on bacterial LPS. Int Endod J 2003;36:733739.

18. de Rossi A, Silva LAB, Leonardo MR, Rocha LB, Rossi MA. Effect of rotary or manual instrumentation, with or without a calcium hydroxide $1 \%$ chlorhexidine intracanal dressing, on the healing of experimentally induced chronic periapical lesions. Oral Surg Oral Med Oral Pathol Oral Radiol Endod 2005;99:628-636.

19. Soares JA, Leonardo MR, Silva LAB, Tanomaru Filho M, Ito IY. Effect of rotary instrumentation and the association of calcium hydroxide and chlorhexidine on the antisepsis of root canal system in dogs. Braz Oral Res 2006;20:120-126.

20. Ferreira FF, Campos Rabang HR, Pinheiro ET, Gadê-Neto CR, Zaia AA, Ferraz CC et al.. Root canal microbiota of dogs' teeth with periapical lesions induced by two different methods. Oral Surg Oral Med Oral Pathol Oral Radiol Endod 2006;102:564-567.

Accepted 29 February, 2008 